\title{
Gender Tendency towards Using Taboo Words Among University Students
}

Mohammad Javad Mohammadi ${ }^{1}$, MiladEini Roumiani ${ }^{2}$, Bizhan Hekmatshoar Tabari ${ }^{3}$

1: Fraydan Branch, Islamic Azad University, Isfahan, Iran

M.mohammadi1377@gmail.com.

2: ShahidChamran University of Ahvaz

Milad.swastika@gmail.com.

3: Ayandegan University of Tonekabon, Iran

Bizhan_hekmat@yahoo.com

\section{Abstract}

There are many factors which affect the language using and language choosing in every society. One of these factors is the controversial factor of gender and its effect on language using and the elements of language used in community and society. To expand the scope of gender-bound language, the current study intends to investigate the use of taboo words among the university students by both genders. To this aim, 40 students, 20 males and 20 females were selected to be compared using a researcher made 15 items questionnaire questioning the participants about using taboo words in specific situations. The results reveal that using taboo words by two groups is not of significant difference except in some situations.

Keywords: gender; sociolinguistics; taboo words.

Discipline: Linguistics (discourse).

Type: questionnaire.

\section{Council for Innovative Research}

Peer Review Research Publishing System

Journal: Journal of Advances in Linguistics

Vol 3, No. 2

editor@cirworld.com

www.cirworld.com, member.cirworld.com 


\section{INTRODUCTION}

Every society and community has its own language, and this language is a kind of norm among the people of that society. According to Shitemi (2009) language is practice of communication which is interchanged by linguistic system(s). System of languages requires the linguistic competence about the knowledge of language for producing and understanding and getting the linguistic structures (Shitemi, 2009). In every society there are many factors which have many effects on language systems and language applications. One of these factors is the controversial factor of gender and its effect on language using. In any society many people use language and these people are in both gender of females and males, but the relationship of gender and using some aspects of language is a kind of challenging discussion. Here something is worth to mention for more understanding of differences between sex and gender, and as Coates (2004, cited in Ekström, 2008) says sex distinguishes men and women in a biological way, while gender is used to explain socially constructed categories based on sex.

Everyday life involves using many words and many phrases and also many sentences, but without paying attention to the gender of people and the way they use or state some kind of language structures. Language and gender are related to the interpretation and also the use of linguistic resources to get the social ends (Eckert \& McConnell-Ginet, 2005, cited in Shitemi, 2009). It is believed that men are generally more influential than women, although the gender difference depends on several mediators (Carli, 2001). Swearing or using taboo words is an interesting aspect of language which is usually not taught or received from authority sources such as parents, teachers, and politicians (Thelwall, 2007). Telwall (2007) believes that using these words is tightly related to the roles of gender and the society's expectations, and the taboo or swearing words are usually related to taboo affairs. Jay (2009) states that taboo words are defined and banned by institutions and sources of power including religion, media, and etc. and prohibitions are repeated in children training and also other training programs related. This definition is also observable in our societies and taboo words or terms are strongly avoided and condemned in formal social aspect of life. In private and friendly societies, however, this issue is totally different and especially among teenagers and younger people, taboo word or swearing wordis used as much as other terms in any language.

In many societies taboo words have no social or formal place, but are not inevitable. People around the world use taboo words in many different situations, and in Iran societies (language communities) taboo words are used but not in every day and at every time in every place. In Iran societies because of the ethical rules and also religious rules people try not to use taboo words so much, but it is hard to say no one uses taboo words. Peopleaffected by many factors including angriness and happiness may use taboo words.

In formal and informal way of living people react to the situations which they are in.For example people are in a bad trouble and they cannot come up with it and they use taboo words and swearing words to soothe their angriness on one hand and in an opposite situation of great happiness also they use taboo words and swearing words to show their happiness. In particular, teenagers and younger people in society use taboo words more than older ones, and this shows that younger and teenagers are more careless about the religion and norms of social formal life. However, this is different cross culturally from one society to another. Since little has been done about using taboo words in Iranian society and especially not about university students (university community), the researcherdecided to do a case study on this matter and investigate the relationship between gender and using the taboo words or swearing words among university students in different situations including happiness, angriness, and also when they are emotionally affected.

\subsection{Research question}

Which group of students use taboo or swearing words in their language use, female students or male ones? What are the factors affecting using taboo words among university students?

\section{LITERATURE REVIEW}

Using language has been always influenced by many factors and linguists and sociolinguists investigate the language and factors which can affect using language. Since language is used in society and in different discourse communities, it is always a central part and in this article gender is the main factor to be investigated. In a study about conversational analysis based on gender differences and using taboo language Ekström (2008) referred to taboo as a forbidden phenomenon everyday life using in general, as well as language. According to Spears (1992, cited in Ekström, 2008) with the advent of women's liberation term and its real concept in the society, and because of their outstanding independent social and economic status, women followed the usual men pattern of forbidden language use for their own purpose. Ekström (2008) believes that various factors affect the people's speech act, among them sex and gender have a particular role.

In her study Ekström (2008) investigated the using taboo language and words in men and women's conversations and also mixed-gender talk in some episodes from the American TV series sex and the city. She examined the differences and similarities of using taboo word in both genders' speech in terms of their gender differences. Based on the data analysis and the results Ekström (2008) concluded that both gender (male and female) characters in the TV series use taboo related language including verbal taboo. Her data showed that both sexes used more taboo language in same-sex context.

Dewaele (2004) in an investigation focuses on the effects of language dominance/attrition, context of acquisition, age of starting the learning, frequency of general use of a language and Sociodemographic variables on self-reported language choice for swearing and using taboo words. In this study, however; hasn't a central role,Sociodemographic 
variables didn't affect. Based on the result of his study Dewaele (2004) finds that frequency of language choice for swearing was found to be positively correlated perceived emotional force of swearwords in that language. At the end Dewaele (2004) concludes that multilinguals' choice of a language for swearing or taboo words is determined by several independent variables which are all related to the individuals' linguistic history.

In another study Dewaele (2004) considers the emotional force of swearwords and taboo words in the speech of multilinguals. Dewaele (2004) says the main reason for his investigation is the interesting paradox concerning use of swearwords in second language. Knowledge of swearwords and taboo words in a second language allows one to be in touch with others on one hand and it can be a source of shame and embarrassment on the other hand when used inappropriately by second language learner or non-native speakers (Dewaele. 2004). Based on the results of his studyDewaele (2004) concluded that the understanding of emotional force of swearwords and taboo words in the multilinguals' different languages is determined by several independent variables, especially those related to the people's linguistic history (how and when the language was learned, what general level of activation does the language have, how frequently has it been or is it being used). Sociodemographic variables showless effects on this matter. At the end Dewaele (2004) believes that perceived emotional force of swearwords and taboo words is higher in the first language of speakers and is gradually lower in languages learned by people beside their native language. He also concluded that female participants tend to show higher scores to the effects of emotional force of swearwords and taboo words but education level and age had no effect.

De Klerk (1992) investigated the using of taboo words in another way and somehow differently. She studies the taboo words using by girls and comes to a conclusion that also girls can use taboo or swearing words more in some cases.Based on the results obtained from the data base in South Africa strongly support her findings and challenge the assumption that women use and believe in standard speech, mentioning evidence that young females are enough familiar with a wide range of highly taboo/slang or swearing items themselves and also use them as well (de Klerk, 1992).At the end three area of concern come to the conclusion for de Klerk (1992) and the first one is that women who are supposed to follow the standard speech rules parallel in South Africa and also North America don't go in the desired direction and this happens because of the more freedom for the ladies around these areas. Second, because of the lexical bias in favor of women showed in the analysis, greatattention required to be zoomed on the question of the difference between biases within the mental lexicon of individual speakers and biases within the lexicon of the language. Third, results of the study point to a need to look more carefully and closely on understanding of the speakers about the terms of taboo, swearing words, and slang and how they distinguish the differences.

Harris, Ayçiçegi, and Gleason (2003) investigated the measure of autonomic reactivity relationship with taboo words and reprimand elicit in a first language and a second language.In this study Harris, Ayçiçegi, and Gleason (2003) claim that it is easier for bilingual speakers to say some kinds of emotionally elicited words or expressions in a language that is not their native language. The authors of the article concluded that taboo words and reprimands elicited stronger physiological responses, as measured by skin conductance, in speakers' L1 than did equivalent words in their L2, which was learned after the age of 12.

Newman, Groom, Handelman, and Pennebaker(2008) in their study examined the gender differences in language use by using standardized categories to analyze a database of over 14,000 text files from 70 separate studies. In their study they found that women use more psychological and social related processes words, and men refer more to object properties in an unfriendly way. They believe that although these effects were largely the same within the different contexts, the pattern of variation suggests that gender differences are larger on tasks that place fewer limitations on language use.

Variations in language use across gender both biologically and socially was studied and investigated by Bell, McCarthy, and McNamara (2006). In their study Bell, McCarthy, and McNamara (2006) define the biologically differences between the two genders, they also assume that based on the social construction theory about gender, differences in language use rely on the context in which the interactions occur. By using a qualitative linguistic approach toward the investigation of gender differences in language use within a context of marital conflict they found that differences appeared in self-references and not in the use of social words and positive negative emotion words. The results of their study show a failure in supporting the sociological theory and provide preliminary evidence for the biological theory.

In another case of investigation and study Mercury (1995) considers the taboo which is called the bad part of language as a good part of language learning. He argues that class treatment of taboo language can be lucrative for language learning. Mercury (1995) points that it doesn't mean that all groups of ESL/EFL learners would take advantage and teachers are not going to teach their students how to swear in English. However, he believes that learners need to know what creates "obscene" language in North American contexts, and why native speakers choose to use it. In his study Mercury (1995) believes that teachers are shy to teach this part of language and they put this important part of language aside. At the end Mercury (1995) concludes that second language learners might get an unusual idea of obscene language use because of the influence movies, hit songs, and popular books where obscene language seems to flow unchecked. Nonetheless, students in learning conversational English need to learn what is acceptable or unacceptable in taboo language behavior.

\section{METHODOLOGY}

\subsection{Participants}


The aim of this study is to consider the use of taboo language by two genders and specifically by university students. To this aim the participants are selected from university students from Chamran University of Ahvaz. Their ages range from 21 to 33 with an average of 24.7. The number of participants is 40 students, 20 females and 20 males.

\subsection{Instrument}

The instrument of the present study is a questionnaire prepared by the researcher, and includes 15 questions about using taboo language in different situations and each question has three choices of Yes, Never, and Sometimes. The participants are required to answer each question and they should just choose one choice or option. The questionnaire is prepared with regard to the emotional situations which the participants might be in at any time of the daily life whether a bad situation or a very exciting or good one.

\subsection{Procedure}

With respect to the aim of the study the questionnaire papers were distributed among the participants and then they had a time to answer the questions with assuming themselves in the situation that has been brought in the questions of the questionnaire.After answering the questionnaires, the obtained data collected and the results and answers of the participants were analyzed carefully by the SPSS software.

\section{DATA ANALYSIS}

Obtained data were gathered thoroughly and also analyzed. The variables which are genders and ages were coded and given to the SPSS software for further and closer analysis. For this aim the independent sample T-Test was applied and the alpha level which is the level of likelihood was 0.05 . Also the significance of the answers to the questions involved in the questionnaire was considered if any difference was observed and as can be seen in the table 1 there was not such a difference between the aimed groups in using taboo words.

Table1.Mean, St. Deviation, and $\mathrm{t}$ related to the gender and using taboo words

\begin{tabular}{|c|c|c|c|c|c|c|}
\hline Gender & Mean & St. Deviation & $t$ & \multicolumn{2}{|c|}{ df } & $p$ \\
\hline Males & 30.6000 & 6.42692 & 0.206 & $\begin{array}{c}\text { Equal variances } \\
\text { assumed }\end{array}$ & 38 & 0.071 \\
\cline { 1 - 2 } & 30.2500 & 4.06364 & & $\begin{array}{c}\text { Equal variances } \\
\text { not assumed }\end{array}$ & 32.098 & \\
\hline
\end{tabular}

In table 1 the significance value for the $P=a l p h a$ was assumed less than 0.05 and as it is indicated in the table the obtained value is more than it. In this sense there is no difference in using taboo words or taboo language between two groups which were selected for the aimed study. Also in another analysis the two groups were compared according to their answers to the questions and each question significance by the answers supplied and the statistics related to this matter provided in table 2.

Table2. Chi square

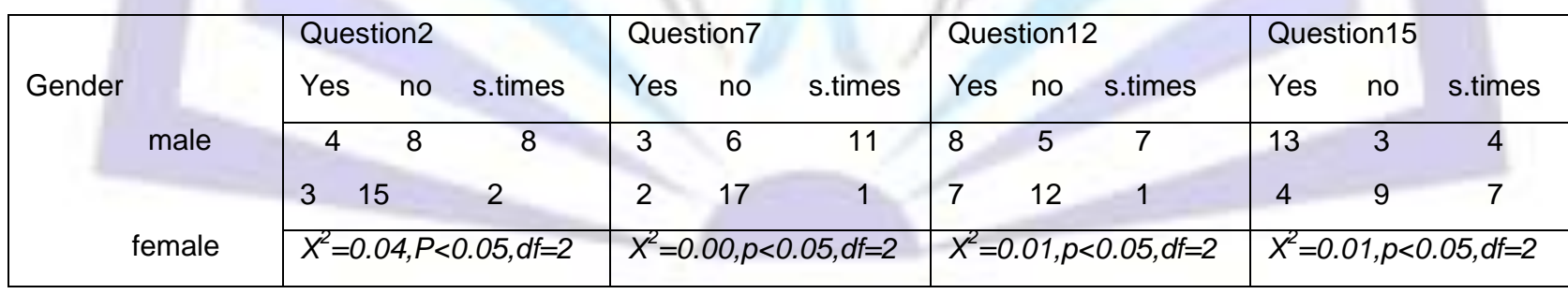

\section{RESULTS}

This case study aims to investigate the use of taboo words or taboo language among two genders of males and females and specifically university students. As it is revealed in the data analysis and tables (table 1) there is no difference between two genders in using taboo words or taboo language. This result is obtained from the amount of significance which formerly said to be less than 0.05 , and referring to this amount there is no difference. Table 2 shows the significance and the statistics related to each question individually, and is shows that some about four items have the relevant significance and it means that some questions have been answered by a group more than the other.

\section{DISCUSSION AND CONCLUSION}

The aim of the present study was to investigate the using of taboo words by both gendersof female and male students to find out which group use more taboo words than the other. By analyzing the data obtained from the participants of the study, and with the aim to consider the using of taboo words in both genders, there was no significant difference between two groups in using taboo words. However, in some circumstances it seems that male group use more 
taboo words than females. In university society as a small community which shows some characteristics of the macrocosm and the real society outside the university, limitations in socialinteraction is more imposed on the speaking of females. In Iranian society it is not normal and usual for females to use taboo words in any situation, and they care about their words and their prestige by using less and no taboo words like males.

In contrast with females' constraint in speaking, males use taboo words more freely and less with caution about using swearing words. It is something marked for females using taboo words and unmarked for males. Malesdo not consider using taboo words as a bad behavior in everyday life. Females but consider using taboo words as a sign of disgrace in social life, and if somebody uses these kinds of words she is belonged to the low class of society and others call this a bad sign for social respect. Males are more concern about their friendship and relations with their friends than females, and if something bad happens about their friendships, they will be more affected by their feelings and emotions in comparison to the females. Males use more taboo words for controlling their feelings and emotions because they think it is better than taking an unusual action when they are under the control of their feelings and emotions.

In this study results show that males in their friends' community do not consider using taboo words as something bad or a disrespecting sign, because they know the situations and their friends well. In this case again females do not use taboo words like males, this kind of behavior reveals that females in most of the situations do not like to use taboo words and consider it as a stigmatizing sign in someone's behavior.

\section{References}

Bell, C., McCarthy, P., \& McNamara, D. (2006).Variations in language use across genderbiological versus sociological theories. University of Memphis.

Carli, L. (2001). Gender and social influence.Wellesley College.Journal of Social Issues. 57(4), 725-741.

De Klerk, V. (1992). How taboo are taboo words for girls? Cambridge University Press. Language in Society.

Dewaele, J-M. (2004). Theemotional force of swearwords and taboo words in the speechof multilinguals. School of Languages, Linguistics and Culture, Birkbeck College,University of London, London, UK.Journal of Multilingual and Multicultural Development.

Dewaele, J-M. (2004). Blistering barnacles! Whatlanguage do multilinguals swear in?! BirkbeckePrints: an open access repository ofresearch output of Birkbeck College. Estudios deSociolinguistica 5(1) 83-105.

Ekström, A. (2008). An analysis of gender differences in using taboo language inconversation. Taboo language in sex and the city.Kristianstad University.

Harris, C., Ayçiçegi, A., \& Gleason, J-B. (2003). Taboo words and reprimands elicit

greater autonomic reactivity in a first language than in a second language. AppliedPsycholinguistics 24, 561-579.

Jay, T. (2009).The utility and ubiquity of taboo words.Massachusetts College of Liberal Arts.Perspectives on Psychological Science.

Mercury, R-E. (1995). Swearing: a "bad" part of language: a good part of language learning. Tes/ Canada journal/revue tes/ duCanada, 13(1).

Newman, M., Groom, C., Handelman, L., \&Pennebaker, J. (2008).Gender Differences inanguage Use: An Analysis of 14,000 Text Samples. Discourse Processes, 45,211-236.

Shitemi, N. (2009). Language and gender.Moi University. IUPUI Fulbright-hays groupprojects abroad program.

Thelwall, M. (2007).Fk yea I swear: Cursing and gender in a corpus of MySpace pages.School of Computing and Information Technology, University of Wolverhampton.Retrieved from: http//:www.scit.wlv.ac.uk/ cm1993/papers/MySpaceSwearing_online.doc 